\title{
Leptin Induces Mitosis and Activates the Canonical Wnt/ $\beta$-Catenin Signaling Pathway in Neurogenic Regions of Xenopus Tadpole Brain
}

\author{
Melissa Cui Bender, Christopher J. Sifuentes and Robert J. Denver* \\ Department of Molecular, Cellular and Developmental Biology, University of Michigan, Ann Arbor, MI, USA
}

In addition to its well-known role as an adipostat in adult mammals, leptin has diverse physiological and developmental actions in vertebrates. Leptin has been shown to promote development of hypothalamic circuits and to induce mitosis in different brain areas of mammals. We investigated the ontogeny of leptin mRNA, leptin actions on cell proliferation in the brain, and gene expression in the preoptic area/hypothalamus of tadpoles of Xenopus laevis. The level of leptin mRNA was low in premetamorphic tadpoles, but increased strongly at the beginning of metamorphosis and peaked at metamorphic climax. This increase in leptin mRNA at the onset of metamorphosis

OPEN ACCESS

Edited by:

Maximilian Michel,

University of Michigan, USA

Reviewed by:

Suraj Unniappan,

University of Saskatchewan, Canada

Vance Trudeau,

University of Ottawa, Canada

${ }^{*}$ Correspondence:

Robert J. Denver

rdenver@umich.edu

Specialty section:

This article was submitted to Experimental Endocrinology,

a section of the journal

Frontiers in Endocrinology

Received: 01 March 2017 Accepted: 20 April 2017

Published: 08 May 2017

Citation:

Bender MC, Sifuentes CJ and Denver RJ (2017) Leptin Induces Mitosis and Activates the Canonical Wnt/ $\beta$-Catenin Signaling Pathway

in Neurogenic Regions of Xenopus Tadpole Brain.

Front. Endocrinol. 8:99. doi: 10.3389/fendo.2017.00099 correlated with increased cell proliferation in the neurogenic zones of tadpole brain. We found that intracerebroventricular (i.c.v.) injection of recombinant Xenopus leptin (rxLeptin) in premetamorphic tadpoles strongly increased cell proliferation in neurogenic zones throughout the tadpole brain. We conducted gene expression profiling of genes induced at $2 \mathrm{~h}$ following i.c.v. injection of rxLeptin. This analysis identified 2,322 genes induced and 1,493 genes repressed by rxLeptin. The most enriched Kyoto Encyclopedia of Genes and Genomes term was the canonical Wnt/ $\beta$-catenin pathway. Using electroporation-mediated gene transfer into tadpole brain of a reporter vector responsive to the canonical $W n t / \beta$-catenin signaling pathway, we found that i.c.v. rxLeptin injection activated Wnt/ $\beta$-catenin-dependent transcriptional activity. Our findings show that leptin acts on the premetamorphic tadpole brain to induce cell proliferation, possibly acting via the $\mathrm{Wnt} / \beta$-catenin signaling pathway.

Keywords: leptin, neurogenesis, Xenopus, metamorphosis, Wnt/ $\beta$-catenin

\section{INTRODUCTION}

Leptin is a protein hormone secreted by adipocytes that signals energy stores to the adult brain. The plasma concentration of leptin fluctuates in proportion to fat mass, and leptin acts on feeding control centers in the hypothalamus to suppress food intake and increase whole body metabolism (1). Leptin (lep) and its receptor (LepR) are widely expressed, and the hormone has been shown to have pleiotropic actions in physiology and development of diverse vertebrate species $(2,3)$. The actions of leptin are mediated by the long form of the LepR (LepRb), which engages several intracellular signaling pathways, especially the Janus kinase $2 /$ signal transducer and activator of transcription (JAK2/STAT) $(4,5)$ and phosphoinositide 3-kinase (PI3K) signaling pathways $(6,7)$.

Recent findings support that leptin has important roles in neurological development, especially development of leptin-responsive feeding control circuits in the hypothalamus. Leptin-deficient 
mice $(o b / o b)$ have reduced brain weight, volume, and DNA content that can be restored by injecting leptin $(4,8)$. Leptin induces mitosis in several brain areas in rodents (8-10), and in tissue culture $(11,12)$, and this role for leptin is likely related to the brain size defects seen in $o b / o b$ mice. The hormone also promotes formation of neuronal projections among hypothalamic nuclei involved with feeding (13-16).

In rodents, serum leptin concentration increases markedly in the neonate, then declines in the juvenile adult (17-19). This "postnatal leptin surge" may play a critical role in the development of the hypothalamic feeding control circuit $(13,15,16)$. Cells in the ventricular zone (VZ)/subventricular zone (SVZ) of the third ventricle $(3 \mathrm{~V})$ of neonates express functional LepR; LepR mRNA expression declines in the VZ/SVZ through development then appears in the arcuate nucleus and ventromedial hypothalamus (18). The LepR is expressed within the VZ of the $3 \mathrm{~V}$ in embryonic/fetal brain $(18,20)$ and these neural progenitor/stem cells (NSCs) may be precursors of hypothalamic feeding control and hypophysiotropic neurons of the adult (21).

Genes for lep have now been isolated from numerous mammalian species, birds, reptiles, amphibians, and fishes $(2,3,22)$. Our earlier findings in Xenopus support that the adipostat function of leptin was present in the earliest tetrapods $(23,24)$. By contrast, a role for leptin in feeding and energy balance in fishes remains unresolved $(2,3)$. Like mammals, tadpoles of Xenopus laevis develop competence to respond to leptin signaling during the postembryonic developmental period of metamorphosis (Melissa Cui Bender and Robert J. Denver, unpublished data). We found that functional LepR is expressed in regions surrounding the $3 \mathrm{~V}$ of premetamorphic tadpole brain, suggesting that leptin can act within tadpole neurogenic zones. In the current study, we investigated whether leptin can promote mitosis in developing Xenopus tadpole brain by administering recombinant Xenopus leptin (rxLeptin) to premetamorphic tadpoles by intracerebroventricular (i.c.v.) injection, then we analyzed cells in $\mathrm{M}$ phase of the cell cycle using immunohistochemistry (IHC) for phosphorylated histone 3 ( $\mathrm{pH} 3$ ). We also conducted a gene expression screen for early ( $2 \mathrm{~h}$ after i.c.v. rxLeptin injection) leptin-induced transcriptional changes in tadpole preoptic area/hypothalamus. This screen identified the canonical Wnt/ $\beta$-catenin signaling pathway as the major intracellular signaling pathway induced by leptin in premetamorphic tadpole brain. Using electroporation-mediated (EM) gene transfer of a Wnt/ $\beta$-catenin-responsive reporter plasmid into tadpole brain, we provide additional evidence that leptin activates functional $\mathrm{Wnt} / \beta$-catenin signaling.

\section{MATERIALS AND METHODS}

\section{Animal Care and Use}

We obtained $X$. laevis tadpoles from in-house breeding and raised them in dechlorinated tap water maintained at $21-23^{\circ} \mathrm{C}$ with a 12L:12D photoperiod. Tadpoles were fed frog brittle twice daily (NASCO, Fort Atkinson, WI, USA) and developmental stages were determined using the Nieuwkoop-Faber (NF) staging table (25). We anesthetized NF stage 50 X. laevis tadpoles (premetamorphic tadpoles) in a buffered solution of $0.002 \%$ benzocaine
(Sigma) before administering i.c.v. injection of rxLeptin [produced as described by Crespi and Denver (23)], or plasmid injections for EM gene transfer (described below). For i.c.v. injection, we used a Drummond microinjector to deliver 50-150 nL of solution containing $0.6 \%$ saline, rxLeptin $(20 \mathrm{ng} / \mathrm{g} \mathrm{BW}$ ) or plasmid DNA, plus $0.01 \%$ fast green dye to the area of the $3 \mathrm{~V}$ as described previously $(23,24,26)$. We chose this dose of rxLeptin based on our previously published work that showed that i.c.v. injection caused a dose-dependent suppression of food intake in the Western spadefoot toad, with $20 \mathrm{ng} / \mathrm{g}$ BW rxLeptin causing maximal suppression (23). Animals were killed by immersion in $0.1 \%$ benzocaine for 2 min before tissue harvest. All procedures involving animals were conducted under an approved animal use protocol (PRO00006809) in accordance with the guidelines of the Institutional Animal Care and Use Committee at the University of Michigan.

\section{RNA Isolation for Gene Expression Analyses}

For developmental analysis of lep mRNA, we extracted total RNA from whole animals beginning at NF stage 45 . For NF stages 45-54, we pooled three animals per replicate and for NF stages $58-66$, one animal per replicate ( $n=5-6 /$ NF stage). We also dissected and isolated total RNA from the portion of the carcass containing the fat pads (we removed tail and other organs; we refer to this as "adipose tissue"), liver, brain, and gut from tadpoles throughout metamorphosis (NF stages 50 , $54,58,62,66)$ for analysis of lep mRNA ( $n=6 / \mathrm{NF}$ stage). For analysis of gene expression by microarray and reverse transcriptase quantitative real-time PCR (RTqPCR), we injected tadpoles i.c.v. with $0.6 \%$ saline or rxLeptin $(20 \mathrm{ng} / \mathrm{g} \mathrm{BW})$, and $2 \mathrm{~h}$ later, we killed the animals, removed the brain, and microdissected the middle region of the brain $(n=6 /$ treatment; the region of the diencephalon containing the preoptic area and hypothalamus, the neuroendocrine and feeding control regions of the brain) (27). We isolated RNA using the Trizol reagent (Invitrogen) following the manufacturer's instructions.

For RTqPCR analysis of gene expression, we developed SYBR Green assays that spanned exon-exon boundaries for each gene. We treated $1 \mu \mathrm{g}$ total RNA with $1.5 \mathrm{U}$ RNase-free DNase I (Roche, Indianapolis, IN, USA) to digest contaminating genomic DNA, then reverse-transcribed the RNA into cDNA using $250 \mathrm{ng}$ random hexamers and Superscript II Reverse Transcriptase (Invitrogen) following the manufacturer's instructions [see also Ref. $(28,29)]$. Minus RT controls were included. Oligonucleotides used for RTqPCR are given in Table 1. We conducted quantitative, real-time PCR using the ABsolute ${ }^{\mathrm{TM}}$ Blue $\mathrm{qPCR}$ SYBR Green Low Rox Mix (ABgene), and reactions were run on an ABI 7500 Fast qPCR machine. Relative quantities were determined using standard curves generated with pooled cDNAs.

\section{IHC for pH3 and Phosphorylated STAT3 (pSTAT3)}

We analyzed the effects of i.c.v. injection of rxLeptin on mitosis in the premetamorphic tadpole brain using IHC for $\mathrm{pH}$. The serine 
TABLE 1 | Sequences of oligonucleotide used to validate microarray results by SYBR Green reverse transcriptase quantitative real-time PCR.

\begin{tabular}{|c|c|c|}
\hline Gene name & Forward & Reverse \\
\hline ctnnb1 & 5' GAATTGGCCACTCGAGCAA 3' & 5' ACCTGGTCCTCGTCATTAAGC 3' \\
\hline sox8 & 5' GGGCAAACTGTGGCGTITA 3’ & 5' CTCAGCCTCCTCCACAAAGG 3' \\
\hline socs3 & 5’ AGAACCTACGCATCCAGTGTGA 3' & 5' GGCACTTCGTGGGTCAGTCT 3' \\
\hline arrb2 & 5' TCAGTCAGACAATACGCAGACATC 3' & 5' GCCACCGGGCCACTTGTAC 3' \\
\hline dab2 & 5' CAGCAGCTGCCACTGGAA 3' & 5' ATTGTTGTGCGTGAGAGTITAC 3' \\
\hline mad2/1 & 5' AAGAACTTGCAACCGTTAAACT 3' & 5' TCACGAACAATGCCGTCTाC 3' \\
\hline rpL8 & 5' TाGCTGAAAGAAATGGCTACATC 3’ & 5' CACGGCCTGGATCATGGA 3' \\
\hline
\end{tabular}

10 at the amino terminus of $\mathrm{H} 3$ is phosphorylated during late G2 through $\mathrm{M}$ phase of the cell cycle and is therefore used to detect dividing cells [for X. laevis brain: (30-32)]. We administered two i.c.v. injections of $0.6 \%$ saline or rxLeptin (200 ng/g BW) (23) into the region of the $3 \mathrm{~V}$ of NF stage 50 tadpoles; the second injection was $24 \mathrm{~h}$ after the first, and tadpoles were killed $48 \mathrm{~h}$ after the first injection (i.e., $24 \mathrm{~h}$ after the second injection). We then processed brains for IHC for $\mathrm{pH} 3$ following the method of Denver et al. (30). Briefly, we prepared $10 \mu \mathrm{m}$ thick transverse cryosections through entire tadpole brains and immunostained sections with a rabbit antiserum against human pH3 (1:500; Cat. \#0650 EMD Millipore, Billerica, MA, USA). Primary immune complexes were detected using a secondary antibody conjugated with Cy3 (1:500, Jackson ImmunoResearch Laboratories, Inc., West Grove, PA, USA). For IHC for pSTAT3, a marker for activated LepR, we administered i.c.v. injections of $0.6 \%$ saline or rxLeptin $(20 \mathrm{ng} / \mathrm{g} \mathrm{BW})(24)$ to NF stage 50 tadpoles and collected brains $1 \mathrm{~h}$ later for fixation and sectioning. We conducted IHC for pSTAT3 on Xenopus brain as described previously (24) using an antiserum generated against a phosphopeptide AP[pY]LK from mouse STAT3 (Tyr705; 1:200; Cat. \# 9131, Cell Signaling), which is $100 \%$ conserved with $X$. laevis STAT3 $(24,33)$. Images of immunostained slides were captured using an Olympus XI-81 microscope, and the total number of $\mathrm{pH} 3$ positive cells per brain was counted. Five brains were analyzed per treatment. Xenopus neuroanatomy is based on Tuinhof et al. (34) with modifications by Yao et al. (35).

\section{DNA Microarray Analysis of Gene Expression after i.c.v. rxLeptin Injection}

We conducted DNA microarray analysis on total RNA isolated from the preoptic area/hypothalamus of NF stage $54 X$. laevis tadpoles $(\sim 0.2 \mathrm{~g} \mathrm{BW}) 2 \mathrm{~h}$ after i.c.v. injection of $0.6 \%$ saline or rxLeptin (20 ng/g BW). We isolated total RNA from microdissected brain regions of three replicate pools (three brains per pool) per treatment. Samples were hybridized to the Affymetrix GeneChip Xenopus laevis Genome 2.0 Array ( $n=3 /$ treatment) at the Affymetrix and Microarray Core Facility at the University of Michigan. We selected a subset of the induced genes to cover a range of expression values (fold change) for validation by RTqPCR (Table 1).

\section{Microarray Data Background Correction, Normalization, and Expression Quantification}

We used the Robust Multichip Average method (36) from the Affy package (v1.52.0) (37) to calculate background-corrected, normalized expression values. Genefilter (v1.56.0) (38) was used to remove uninformative probesets (internal control probesets, or probesets with low variance or background level expression values).

\section{Microarray Data Differential Expression Analysis and Annotation}

Principal component analysis plots of the normalized, filtered samples showed samples of the same treatment (saline or rxLeptin) clustered together, and that the two treatments clustered separately. We used the limma package (v3.30.2) (39) to apply empirically derived array weights to individual samples, which were then used to calculate differential expression values (40). Annotations for each gene were added using the annotation file supplied by Affymetrix for the X. laevis Genome 2.0 Array.

\section{Gene Ontology (GO) and Pathway Analysis}

Gene ontology term enrichment analysis was conducted using a $\log _{2}$ fold change ( $\log _{2} \mathrm{FC}$ ) ranked list from limma, containing genes with a Benjamini and Hochberg $(\mathrm{BH})$-corrected $p$-value, or false-discovery rate $(\mathrm{FDR})<0.05$, as input into clusterProfiler (v3.2.4) (41). This analysis determines which molecular function, biological process, or cellular component GO terms are positively or negatively enriched in rxLeptin-treated samples compared with saline-treated controls, at a $p$-value $<0.05$, while taking into account the magnitude and direction of change. Due to the hierarchical and redundant nature of GO terms, we obtained a summarized list of GO terms using Revigo to remove redundant terms (42).

We conducted Kyoto Encyclopedia of Genes and Genomes (KEGG) (43) pathways enrichment analysis using a $\log _{2} \mathrm{FC}$ ranked list of all differential gene expression data from limma (FDR < 0.05) as input into clusterProfiler (v3.2.4) (41). An additional KEGG module (highly annotated functional units of a metabolic network) enrichment analysis was conducted using the same $\log _{2} \mathrm{FC}$ ranked list as input into clusterProfiler (v3.2.4). Gene expression values for KEGG pathways were plotted on the respective pathways using the pathview package (v1.14.0) (44).

Enriched biological processes GO terms, KEGG pathways, and KEGG modules were displayed using the Enrichment Map application (v2.2.0) (45) in Cytoscape (v3.4.0) (46).

\section{EM Gene Transfer and In Vivo Reporter Assay}

We used EM gene transfer $(30,47-50)$ and i.c.v. microinjection of $0.6 \%$ saline or rxLeptin (20 ng/g BW) to investigate whether 
leptin can activate the Wnt/ $\beta$-catenin signaling pathway in tadpole brain in vivo. We divided NF stage 50 tadpoles into three groups for bipolar electroporation. Tadpoles were electroporated with a DNA mixture containing pRenilla-null $(50 \mathrm{ng} / \mu \mathrm{L}$; for dual-luciferase assay normalization), pCMV-eGFP (500 ng/ $\mu \mathrm{L}$; to visualize transfection efficiency), and one of the following firefly luciferase reporter vectors (each at $1 \mu \mathrm{g} / \mu \mathrm{L}$ ): pGL4.23 empty (negative control), GAS-luciferase (positive control for leptin activity) $(23,24)$ or pGL4.23-6TCF (reporter of activated canonical Wnt/ $\beta$-catenin signaling). The pGL4.23-6TCF vector contains six $\mathrm{T}$ cell factor (TCF) sites upstream of a minimal promoter driving luciferase expression, and therefore reports activation of the canonical Wnt/ $\beta$-catenin signaling pathway (gift of Dr. Ken Cadigan). A separate group of tadpoles received pGL4.23-6TCF, pRenilla-null, and pCMV-EGFP plus a constitutively active $\beta$-catenin expression vector pcDNA3-S33Y $\beta$-catenin (51) (gift of Dr. Eric Fearon) or an empty vector (pCMVneo-empty). Plasmid concentrations for electroporation are based on Yao et al. (52). Twenty-four hours after EM gene transfer we screened tadpoles for strong GFP expression, and then separated them into eight groups: pGL4.23-empty reporter, saline, or rxLeptin; GAS-luciferase, saline, or rxLeptin; pGL4.23-6TCF, saline, or rxLeptin; pGL4.23-6TCF, pCMVneoempty, or pcDNA3-S33Y $\beta$-catenin. Tadpoles receiving i.c.v. injections were given saline or rxLeptin (20 ng/g BW). Two hours after injection, tadpoles were killed and brains harvested for dual-luciferase assay following the protocol described by Yao et al. (52). We had a sample size of eight tadpoles per treatment.

\section{Data and Statistical Analysis}

We analyzed data for gene expression by RTqPCR, $\mathrm{pH} 3$ cell counts and dual-luciferase assay data by one-way ANOVA or by unpaired Student's $t$-test $(p<0.05)$. Derived values were $\log _{10}$-transformed before statistical analysis. Fisher's least squares difference post hoc test was used to separate the means following ANOVA. We used the SYSTAT 13.0 computer program (SPSS Inc.).

\section{RESULTS}

\section{Ontogeny of lep mRNA in Tadpoles during Metamorphosis, and Effects of rxLeptin on Mitosis in Premetamorphic Tadpole Brain}

Whole body lep mRNA increased 3.3-fold between stages 48 and 50, which is immediately before the onset of metamorphosis $(p<0.001$, ANOVA; Figure 1A). The mRNA level increased further (7.6-fold) from stages 50 to 54 , and remained elevated throughout metamorphosis and in the postmetamorphic frog (NF stage 66). The pattern of changes in lep mRNA in adipose tissue during metamorphosis was similar to whole body (Figure 1B; $p=0.002$, ANOVA). By contrast, lep mRNA decreased in liver $(p=0.001)$ and was low and unchanged in brain throughout metamorphosis (Figure 1B). These findings, and other results from our laboratory support that fat tissue is the major source of lep mRNA in the tadpole (Melissa Cui Bender and Robert J. Denver, unpublished data). This developmental pattern of lep
mRNA paralleled changes in cell proliferation in tadpole brain during metamorphosis (Figure 2A) (30). Injection of rxLeptin strongly increased $\mathrm{pH} 3$-immunoreactivity (35-fold; $p<0.0001$; Student's unpaired $t$-test) in cells within the VZ/SVZ throughout the tadpole brain (Figures 2B,C). Also, i.c.v. rxLeptin injection $(1 \mathrm{~h})$ induced the appearance of pSTAT3 immunoreactivity (pSTAT3-ir) in the VZ/SVZ in the region of the $3 \mathrm{~V}$ (Figure 2D), supporting the expression of functional LepR in these cells. The inset in Figure 2D shows a high magnification view of the VZ/SVZ with elongated cells undergoing migration out of the neurogenic zone.

\section{i.c.v. rxLeptin Injection Induces Rapid Transcriptional Responses in Early Premetamorphic (NF Stage 54) Tadpole Brain}

To investigate the molecular basis for leptin action on tadpole brain, we conducted microarray analysis on the region of the diencephalon containing the preoptic area/hypothalamus of $\mathrm{NF}$ stage 54 tadpoles at $2 \mathrm{~h}$ following i.c.v. injection of $0.6 \%$ saline or rxLeptin injection (20 ng/g BW). The transformed log ratio (M) and mean average (A) plot (MA plot) in Figure $\mathbf{3 A}$ shows that the data are normally distributed, with a zero-centered transformed $\log$ ratio. Additionally, this plot shows that genes with a significant $\mathrm{BH}$-adjusted $p$-value (FDR < 0.05), plotted in red, are distributed evenly across MA expression levels, indicating an ability to detect differentially expressed genes at any range of expression. This plot also indicates that an absolute log2 fold change (log2FC) as low as $\sim 0.5$ can be detected with confidence (FDR $<0.05$ ). This analysis identified 2,322 induced and 1,493 repressed genes (Table S1 in Supplementary Material). The top 20 induced and repressed genes are given in Tables $\mathbf{2}$ and 3, respectively. The microarray dataset has been deposited in the Gene Expression Omnibus archive at the National Center for Biotechnology Information (GEO accession \#GSE97243).

Using these differential expression data, we conducted several enrichment analyses, allowing us to classify the global gene regulation changes into several general categories (general biological process regulation, metabolism, cellular components, adhesion, immune signaling, cell signaling, development, cell division and neurogenesis, and others) and highlighting several biological processes or pathways of interest. The enrichment map in Figure 3B shows these data: enriched biological process GO terms ( $p$-value $<0.15$ ), KEGG pathways ( $p$-value $<0.15$ ), and KEGG modules. We validated a subset of the induced genes by RTqPCR (Figure 4).

The top ten GO terms involved developmental processes (Figure 3B; Table 4; Table S2 in Supplementary Material). Noteworthy is the $\mathrm{Wnt} / \beta$-catenin signaling pathway, which was found by each enrichment analysis (biological process GO, KEGG pathway, KEGG module; Figure 5). Also, signaling by two TGF $\beta$ family members, bone morphogenetic protein (BMP) and activin, was among the enriched KEGG modules (Figure 6; Table S3 in Supplementary Material; tab KEGGmodules.filt). The hedgehog and insulin signaling pathways were also found to be enriched (Figures S1 and S2 in Supplementary Material). 
A

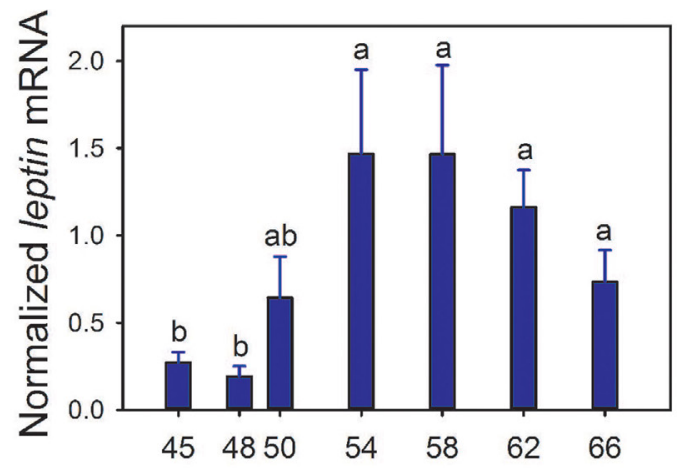

Developmental Stage (NF)

B
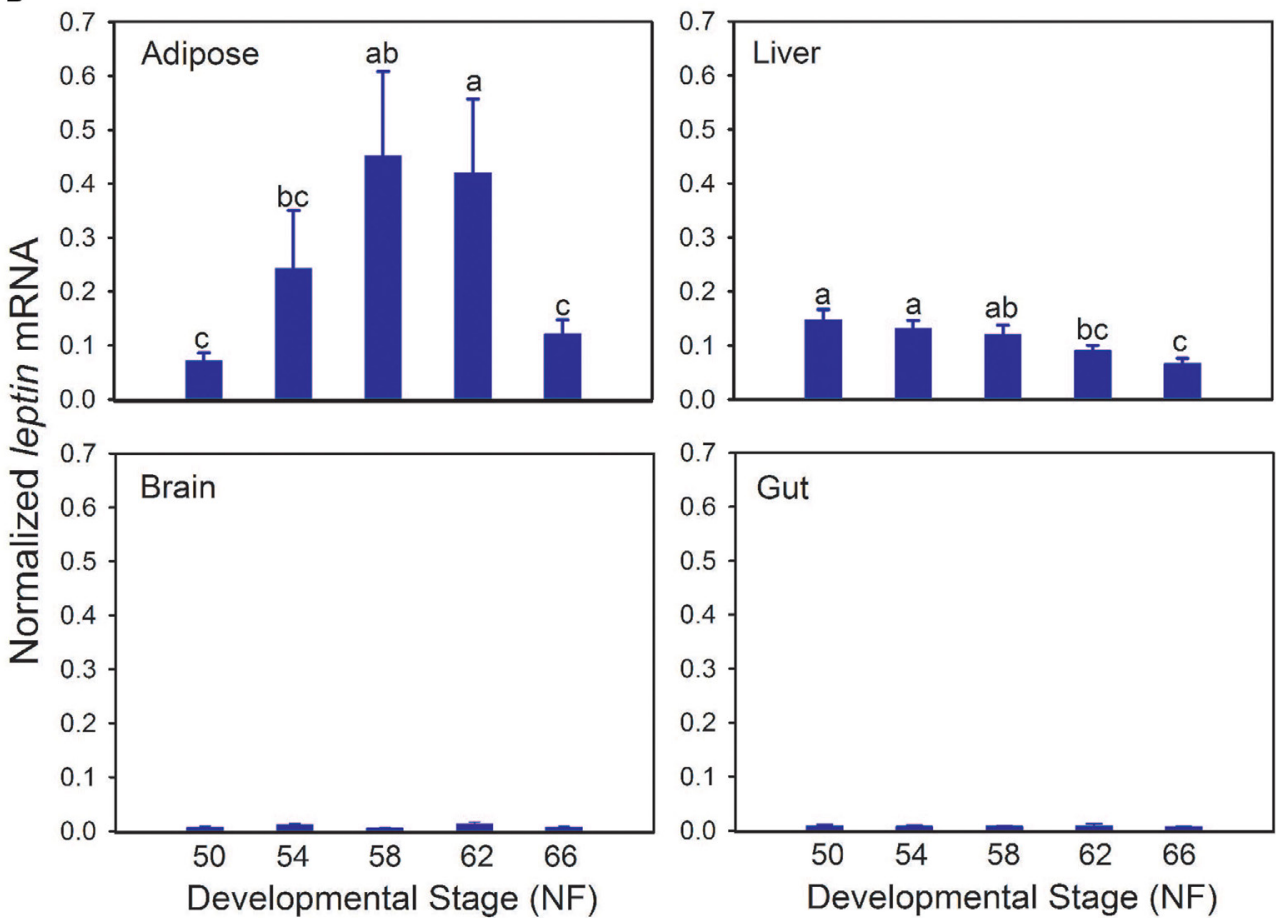

FIGURE 1 | Transcription of the lep gene is activated during tadpole metamorphosis. (A) Whole body lep mRNA increases during tadpole metamorphosis. (B) Developmental changes in lep mRNA in four tadpole tissues during metamorphosis. We analyzed lep mRNA by reverse transcriptase quantitative real-time PCR. Note that the scales of the graphs in panel (B) are not directly comparable to the graph in panel (A) since the samples were analyzed in separate assays using a relative quantification method (see Materials and Methods). Means with the same letter are not significantly different $[p<0.05$; Fisher's least squares difference test; $n=5-6 /$ Nieuwkoop-Faber (NF) stage].

\section{Wnt/ $\beta$-Catenin Signaling Is Activated in Premetamorphic Tadpole Brain by i.c.v. rxLeptin Injection}

To test if leptin can activate the canonical Wnt/ $\beta$-catenin signaling pathway in tadpole brain in vivo, we conducted EM gene transfer with different reporter plasmids, and injected saline or rxLeptin i.c.v. Injection of rxLeptin did not alter luciferase activity in pGL4.23-empty vector-transfected brain, but caused a strong increase (12.9-fold; $p<0.0001$, unpaired Student's $t$-test) in luciferase driven by the GAS-luciferase vector, which reports pSTAT3 signaling induced by leptin binding to the LepR (Figure 7) $(23,24)$. This confirmed activation of LepR signaling in tadpole brain after i.c.v. rxLeptin injection. We observed a threefold increase in luciferase activity $(p<0.001)$ driven by the pGL4.23$6 \mathrm{TCF}$ (Wnt/ $\beta$-catenin pathway) reporter vector following injection of rxLeptin. Forced expression of constitutively active $\beta$-catenin confirmed the activity of the pGL4.23-6TCF reporter (47-fold increase; $p<0.0001)$.

\section{DISCUSSION}

Leptin has well-established roles in adult physiology, but its developmental actions are less understood. Here, we show that lep expression increases strongly during tadpole metamorphosis 
A

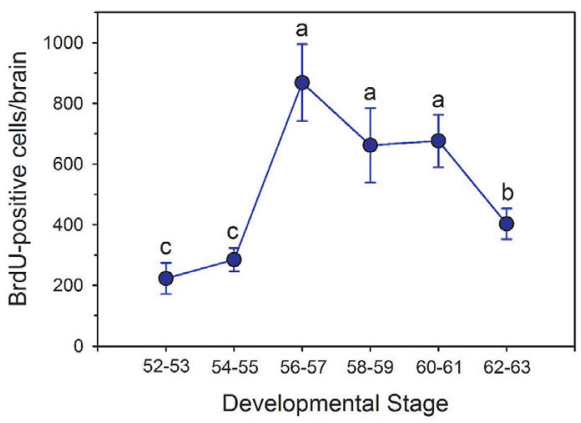

C

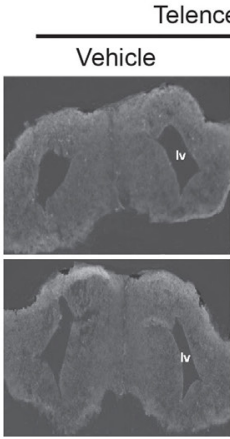

Telencephalon

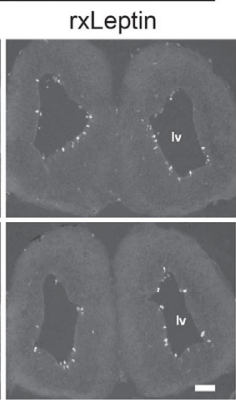

Anterior preoptic area

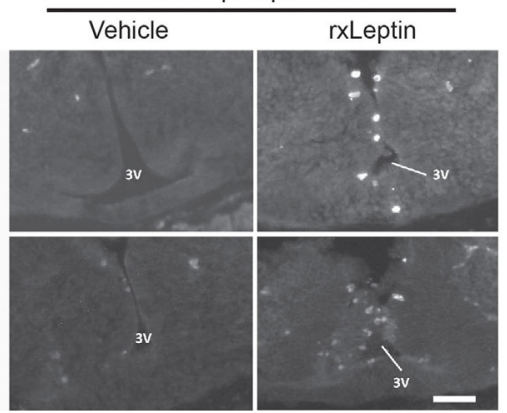

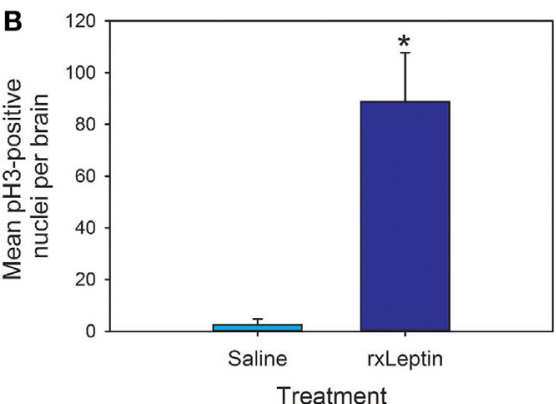

D

FIGURE 2 | Leptin induces mitosis in premetamorphic tadpole brain. (A) Changes in cell proliferation in tadpole brain throughout metamorphosis analyzed by BrdU incorporation [data are modified from Denver et al. (30); reproduced with permission]. (B) Quantification of pH3 positive cells in tadpole brain following intracerebroventricular injection of saline or recombinant Xenopus leptin (rxLeptin) (200 ng/g BW). Tadpoles were given two injections, the second $24 \mathrm{~h}$ after the first, and then they were killed $48 \mathrm{~h}$ after the first injection. *Denotes a statistically significant difference ( $p<0.05$; Student's unpaired t-test). (C) Images of transverse sections of the region of the telencephalon [lateral ventricle (IV)] and anterior preoptic area [location of neurosecretory neuron cell bodies; third ventricle (3V)] of tadpole brain stained for pH3. Scale bars $=120 \mu \mathrm{M}$. (D) Induction of pSTAT3 immunoreactivity in cells located in the ventricular zone (VZ)/subventricular zone (SVZ) of premetamorphic (Nieuwkoop-Faber stage 50 ) tadpole brain by rXLeptin (20 ng/g BW; $1 \mathrm{~h}$ ). The inset shows a higher magnification view of the VZ/SVZ with elongated cells undergoing migration out of the neurogenic zone.

in parallel with an increase in mitosis in tadpole brain. Also, i.c.v. injection of rxLeptin induced mitosis in neurogenic zones of premetamorphic tadpole brain. Gene expression screening identified genes regulated by leptin signaling in early premetamorphic tadpole brain, and highlighted several signaling pathways (Wnt/ $\beta$-catenin, TGF $\beta$, hedgehog, and insulin signaling) through which leptin may effect its regulatory role in neurogenesis. We also show that leptin activates $\mathrm{Wnt} / \beta$-catenin pathway signaling in tadpole brain in vivo, as evidenced by activation of a Wnt $/ \beta$ catenin pathway reporter vector.

\section{Leptin Promotes Neurogenesis in Xenopus Tadpole Brain}

We observed a strong induction of mitosis in neurogenic zones of the premetamorphic tadpole brain following i.c.v. injection of rxLeptin. The rapid increase in pSTAT3-ir in cells of these regions $1 \mathrm{~h}$ after rxLeptin injection supports that they express functional LepR, and therefore that the action of leptin on mitosis is likely to be direct. In rodent embryonic/fetal brain, LepR mRNA is expressed within the VZ/SVZ of the $3 \mathrm{~V}(18,20)$. The LepR mRNA level in the VZ/SVZ declines through development, after which time it appears in the arcuate nucleus and ventromedial hypothalamus (18). These LepR mRNA-expressing NSCs may be precursors of hypothalamic feeding control and hypophysiotropic neurons of the adult (21). The LepR is also expressed in the VZ/ SVZ (progenitor cell niches) of adult monkey brain (53).

Several lines of evidence from studies in rodents support that leptin controls cell proliferation in developing brain and can also induce neurogenesis in adults. For example, the reduced brain weight and DNA content in $o b / o b$ mice is restored by leptin injection $(4,8)$, and leptin has been found to induce mitosis in rodent brain in vivo (8-10), and in tissue culture $(11,12)$. The large increase in lep mRNA in tadpoles during metamorphosis, a postembryonic developmental period that has been compared to the neonatal/early postnatal period in direct developing species like mammals (54), may be similar, both phenomenologically and functionally, to the postnatal leptin surge that occurs in rodents (17-19). It has been hypothesized that this postnatal increase in leptin plays a pivotal role in the development of the hypothalamic feeding control circuitry $(13,15,16,55-56)$. Leptin has also been shown to promote neurogenesis in the hippocampus of adult mammals (57), which may depend on Wnt/ $\beta$-catenin signaling (58). The extra-hypothalamic actions of leptin on adult neurogenesis and neural plasticity may improve cognition and mood in animal models of depression and anxiety, and circulating leptin concentration is negatively correlated with Alzheimer's disease in humans (59), and promotes neurogenesis in a mouse model 
A

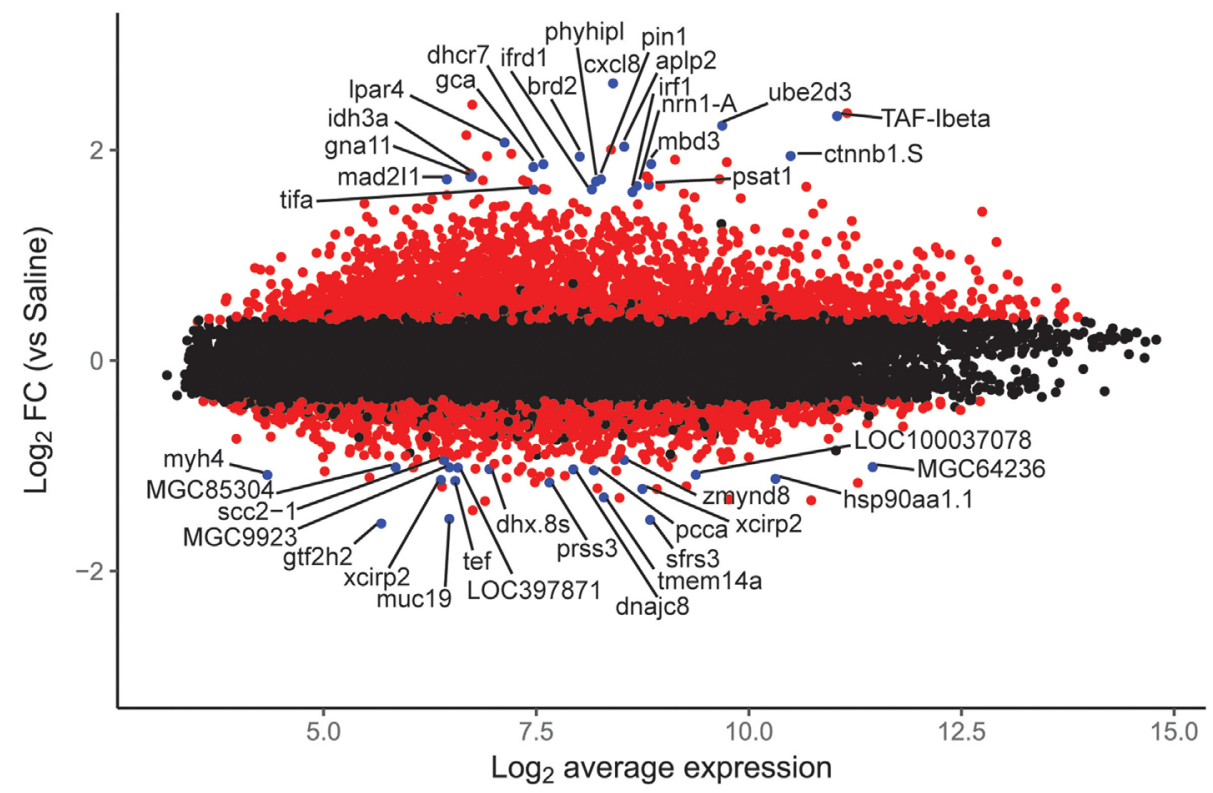

B

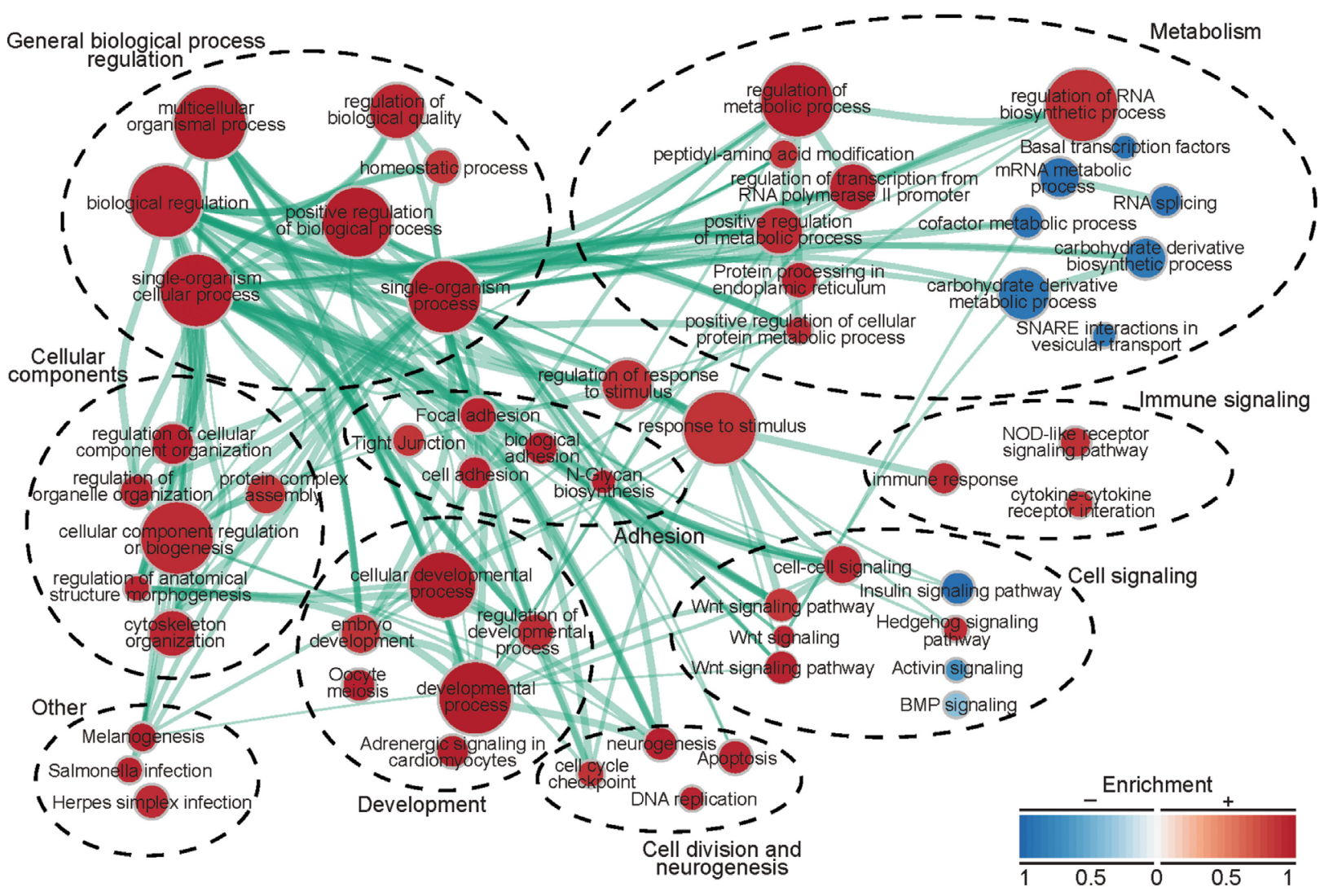

FIGURE 3 | Analysis of microarray data from preoptic area/hypothalamus of saline or recombinant Xenopus leptin (rxLeptin)-injected [intracerebroventricular (i.c.v.) $\mathbf{2 0}$ ng/g BW; $\mathbf{2}$ h] Nieuwkoop-Faber stage $\mathbf{5 4}$ tadpoles. (A) Transformed log ratio and mean average plot [log 2 fold change $\left(\log _{2} \mathrm{FC}\right)$ vs. average expression] of saline vs. rxLeptin-injected tadpole mRNA levels (see Materials and Methods). Dots represent genes: red $=$ genes with a false-discovery rate $<0.05$; blue $=$ top 20 differentially expressed and annotated Xenopus laevis genes; black $=$ all other genes. (B) Biological processes, pathways, and modules affected by i.c.v. rxLeptin injection. Enrichment map of enriched biological process gene ontology terms (redundancy reduced, $p<0.05$ ), Kyoto Encyclopedia of Genes and Genomes (KEGG) pathways $(p<0.05)$, and KEGG modules. Circular node color reflects positive (red) or negative (blue) enrichment. Node color intensity reflects the degree of enrichment relative to the most highly enriched in either direction. Lines (green) represent significant genetic information shared between connected nodes (above 50\%), and line thickness represents the degree of shared information. 
TABLE 2 | Top twenty genes with annotation induced by recombinant Xenopus leptin in premetamorphic tadpole brain.

\begin{tabular}{|c|c|c|c|c|}
\hline Gene symbol & Gene title & Entrez gene ID & $\log _{2}$ fold change & Adjusted $p$-value \\
\hline LOC100036815/CxCl8 & Hypothetical protein LOC100036815/interleukin-8 & 100036815 & 2.63 & 0.00001 \\
\hline ctnnb1 & Beta-catenin protein & 399274 & 2.32 & 0.00013 \\
\hline ube2d3 & Ubiquitin-conjugating enzyme E2D 3 (UBC4/5 homolog) & 403384 & 2.23 & 0.00018 \\
\hline Ipar4 & Lysophosphatidic acid receptor 4 & 779407 & 2.07 & 0.00018 \\
\hline aplp2 & Amyloid beta (A4) precursor-like protein 2 & 431790 & 2.03 & 0.00018 \\
\hline set/TAF-Ibeta1 & SET nuclear oncogene///TAF-Ibeta1 & $379599 / / / 399349$ & 1.94 & 0.00014 \\
\hline brd2 & RING3 protein & 779057 & 1.94 & 0.00028 \\
\hline mbd3 & Methyl-CpG binding domain protein 3 & 398135 & 1.87 & 0.00018 \\
\hline dhcr7 & 7-Dehydrocholesterol reductase & 379273 & 1.87 & 0.00028 \\
\hline gca & Grancalcin, EF-hand calcium binding protein & 444080 & 1.84 & 0.00014 \\
\hline idh3a & Isocitrate dehydrogenase 3 (NAD+) alpha & 444419 & 1.75 & 0.00017 \\
\hline gna11 & Guanine nucleotide binding protein (G protein), alpha 11 (Gq class) & $380535 / / / 779103$ & 1.74 & 0.00026 \\
\hline $\operatorname{pin} 1$ & Peptidylprolyl cis/trans isomerase, NIMA-interacting 1 & 503670 & 1.72 & 0.00018 \\
\hline mad2/1 & MAD2 mitotic arrest deficient-like 1 & 380433 & 1.72 & 0.00074 \\
\hline phyhipl & Phytanoyl-CoA 2-hydroxylase interacting protein-like & 447238 & 1.70 & 0.00037 \\
\hline psat1 & Phosphoserine aminotransferase 1 & 494700 & 1.67 & 0.00013 \\
\hline$n r n 1-A$ & Neuritin 1-A & 373709 & 1.66 & 0.00025 \\
\hline ifrd1/MGC69123 & Interferon-related developmental regulator 1 & $379667 / / / 494857$ & 1.63 & 0.00019 \\
\hline tifa & TRAF-interacting protein with forkhead-associated domain & 734184 & 1.62 & 0.00026 \\
\hline irf1 & Interferon regulatory factor 1 & 398826 & 1.60 & 0.00007 \\
\hline
\end{tabular}

TABLE 3 | Top twenty genes with annotation repressed by recombinant Xenopus leptin in premetamorphic tadpole brain.

\begin{tabular}{|c|c|c|c|c|}
\hline Gene symbol & Gene title & Entrez gene ID & $\log _{2}$ fold change & Adjusted $p$-value \\
\hline gtf2h2/MGC81060 & General transcription factor $॥ \mathrm{H}$ subunit 2 & 443754 & -1.55 & 0.00027 \\
\hline sfrs3 & Splicing factor, arginine serine-rich 3 & 380152 & -1.51 & 0.00018 \\
\hline muc19 & Mucin 19, oligomeric & 378670 & -1.50 & 0.00018 \\
\hline tmem14a & Transmembrane protein 14A & 444418 & -1.30 & 0.00613 \\
\hline xcirp2 & Cold-inducible RNA binding protein 2 & 379484 & -1.22 & 0.00391 \\
\hline prss3 & Protease, serine, 3 & 447093 & -1.16 & 0.01023 \\
\hline tef & Thyrotrophic embryonic factor & 379940 & -1.14 & 0.00018 \\
\hline hsp90aa1.1/MGC82579 & Heat shock protein 90 kDa alpha family class A member 1 & 444024 & -1.12 & 0.00030 \\
\hline myh4 & Similar to myosin, heavy polypeptide 4 , skeletal muscle & 399414 & -1.09 & 0.00145 \\
\hline LOC100037078 & Hypothetical protein LOC100037078 & 100037078 & -1.09 & 0.01290 \\
\hline pсcа & Propionyl Coenzyme A carboxylase, alpha polypeptide & 734347 & -1.04 & 0.00330 \\
\hline dnajc8 & DnaJ (Hsp40) homolog, subfamily C, member 8 & 447089 & -1.03 & 0.00224 \\
\hline dhx.8S/MGC80994 & DEAH-box helicase $8 \mathrm{~S}$ homolog & 444315 & -1.03 & 0.00145 \\
\hline LOC397871 & Larval beta II globin & 397871 & -1.02 & 0.00106 \\
\hline MGC85304 & MGC85304 protein & 447105 & -1.02 & 0.00207 \\
\hline MGC99235 & MGC99235 protein & 447690 & -1.01 & 0.00053 \\
\hline MGC64236 & Hypothetical protein MGC64236 & 379516 & -1.01 & 0.00292 \\
\hline $\operatorname{scc} 2-1$ & Scc2-1B & 445865 & -0.95 & 0.01224 \\
\hline zmynd8 & Zinc finger, MYND-type containing 8 & 733267 & -0.94 & 0.01584 \\
\hline hmgn1/MGC64236 & High mobility group nucleosome binding domain 1 & 379516 & -0.94 & 0.00244 \\
\hline
\end{tabular}

of Alzheimer's disease (60). Leptin has also been shown to be neuroprotective and induces neurogenesis and angiogenesis after stroke (61-63).

Cell proliferation in tadpole brain during metamorphosis depends on thyroid hormone (30). However, other mitogens such as leptin, activators of the TGF $\beta$ pathway, neurotrophins, and insulin-like peptides likely also play important roles in this developmental process. Indeed, there may be synergy between different signaling pathways, some that are affected by nutritional state like leptin and insulin-like peptides, that determine cell expansion and development of neural structures and pathways. Leptin has been found to synergize with thyroid hormone to induce proliferation of chondrocytes in growth plates, and also to promote terminal differentiation (64). Whether similar synergy occurs in the developing brain, which is critically dependent on thyroid hormone for its development, requires further study.

\section{Leptin Activates Canonical Wnt/ $\beta$-Catenin Signaling in Xenopus Tadpole Brain}

Using gene expression screening, we discovered sets of genes that are rapidly induced or repressed by leptin signaling in the tadpole preoptic area/hypothalamus. The major pathways regulated by leptin included the Wnt/ $\beta$-catenin and TGF $\beta$ signaling pathways. 

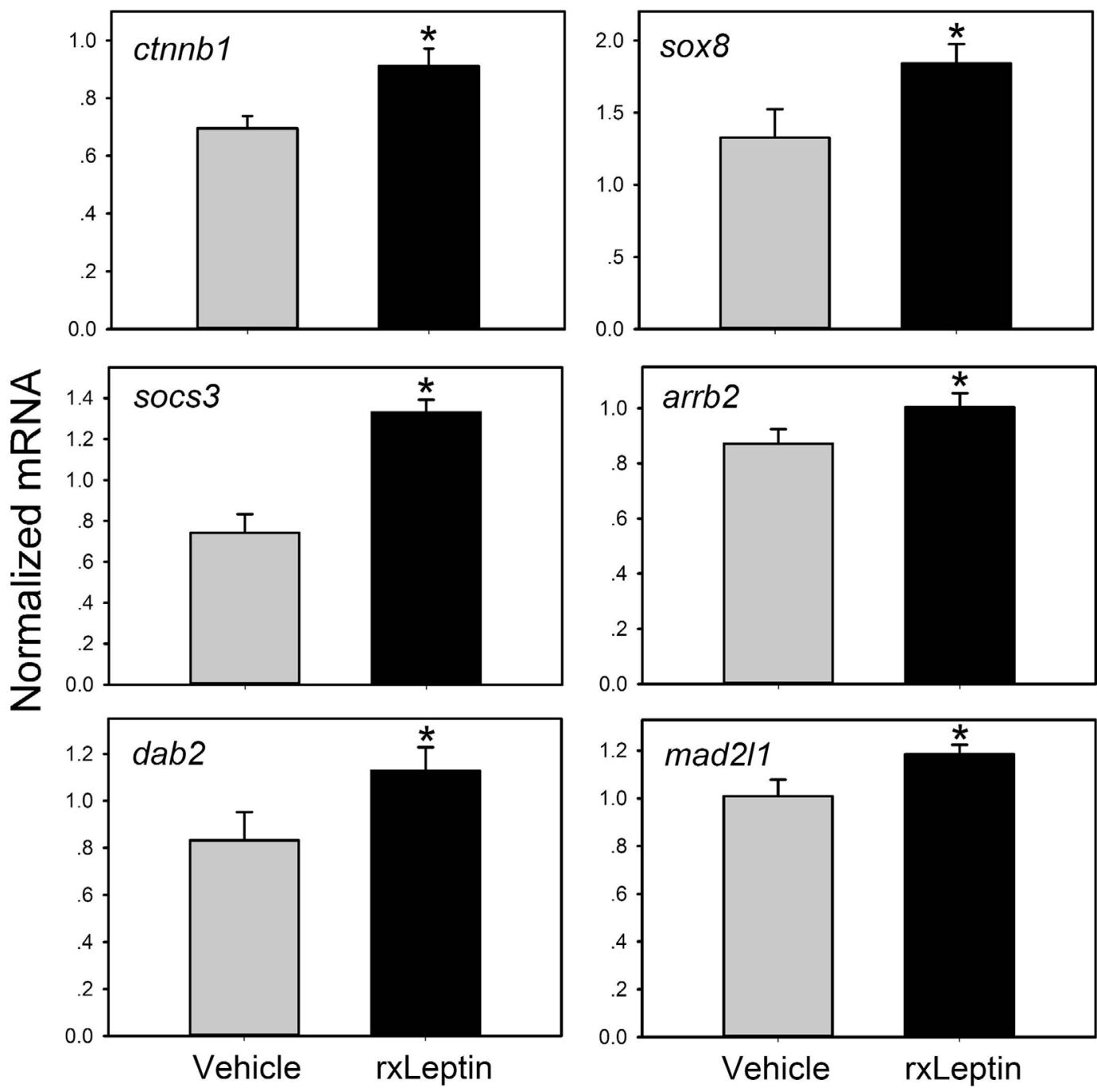

\section{Treatment}

FIGURE 4 | Validation of leptin-induced genes in Nieuwkoop-Faber stage $\mathbf{5 4}$ Xenopus laevis tadpole preoptic area/hypothalamus by reverse transcriptase quantitative real-time PCR (RTqPCR). Tadpoles received an injection intracerebroventricular of $0.6 \%$ saline or recombinant Xenopus leptin (rxLeptin) (20 ng/g BW) and were killed $2 \mathrm{~h}$ later for tissue harvest for RNA isolation. Gene expression was analyzed by SYBR Green RTqPCR and normalized to the reference gene rpL8 which was not affected by rxLeptin injection (data not shown). Asterisks indicate statistically significant differences from saline injected controls $\left({ }^{*} p<0.05\right.$; unpaired Student's $t$-test).

TABLE 4 | Top ten gene ontology (GO) terms corresponding to developmental processes.

\begin{tabular}{|c|c|c|c|c|c|c|c|}
\hline ID & Description & Set size & Enrichment score & NES & $p$-Value & p.adjust & $q$-Values \\
\hline GO:0044767 & Single-organism developmental process & 470 & 0.298665447 & 1.479435427 & 0.00101833 & 0.159221311 & 0.159221311 \\
\hline GO:0048856 & Anatomical structure development & 452 & 0.305758564 & 1.512476805 & 0.00101833 & 0.159221311 & 0.159221311 \\
\hline GO:0032502 & Developmental process & 473 & 0.305340626 & 1.513106572 & 0.001019368 & 0.159221311 & 0.159221311 \\
\hline GO:0044707 & Single-multicellular organism process & 433 & 0.301770432 & 1.490562662 & 0.001023541 & 0.159221311 & 0.159221311 \\
\hline GO:0032501 & Multicellular organismal process & 463 & 0.29984464 & 1.483930907 & 0.00102459 & 0.159221311 & 0.159221311 \\
\hline GO:0007275 & Multicellular organism development & 407 & 0.300744558 & 1.475210668 & 0.003089598 & 0.400102987 & 0.400102987 \\
\hline GO:0030154 & Cell differentiation & 203 & 0.319354548 & 1.47945519 & 0.004429679 & 0.491694352 & 0.491694352 \\
\hline GO:0009790 & Embryo development & 84 & 0.391329957 & 1.634661027 & 0.006157635 & 0.598060345 & 0.598060345 \\
\hline GO:0048513 & Animal organ development & 137 & 0.342563144 & 1.530163684 & 0.007900677 & 0.649743161 & 0.649743161 \\
\hline GO:0048869 & Cellular developmental process & 242 & 0.301733778 & 1.42896268 & 0.008583691 & 0.649743161 & 0.649743161 \\
\hline
\end{tabular}




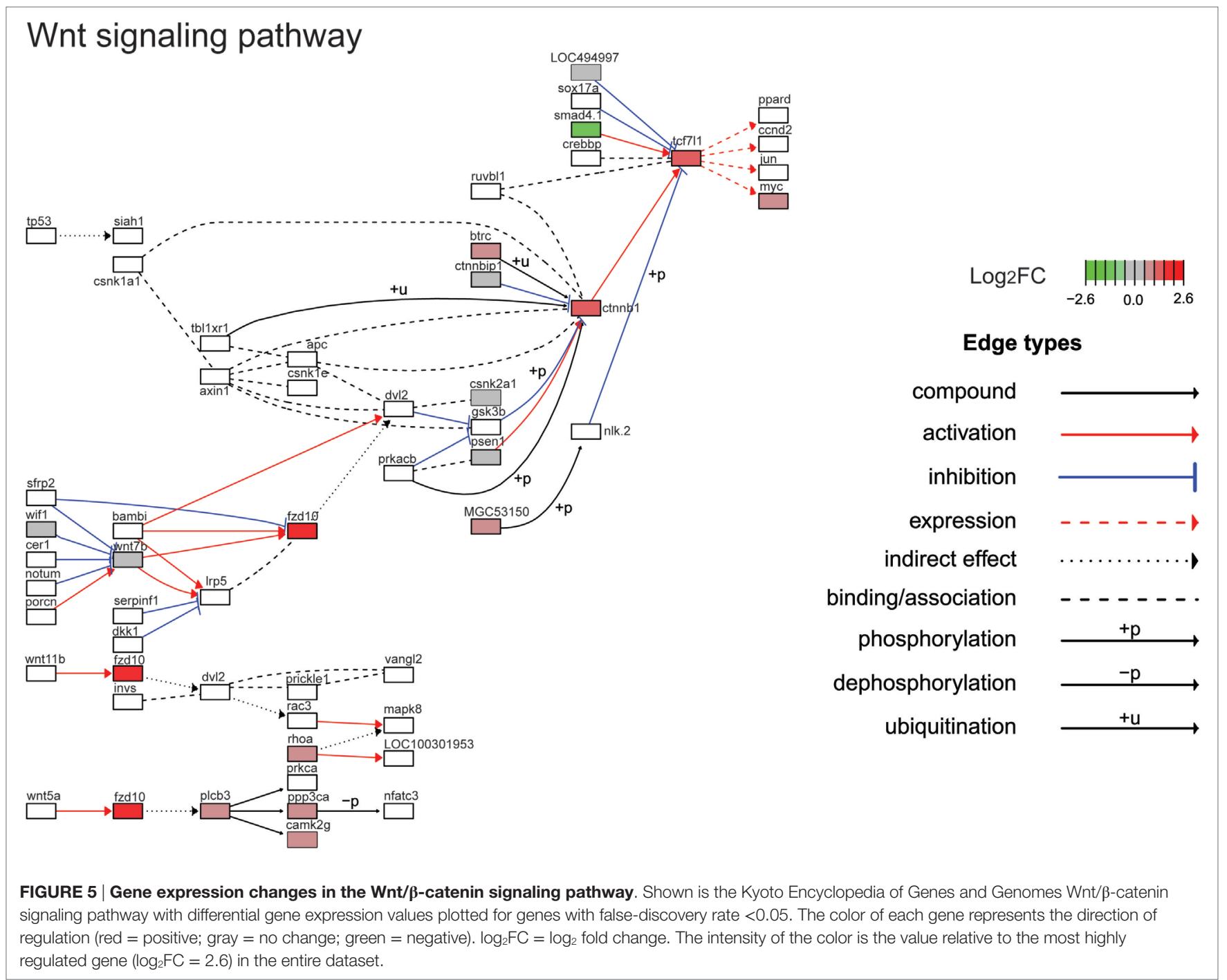

Notably, we identified several genes involved in the Wnt/ $\beta$-catenin signaling pathway, including $\beta$-catenin, the central component of the canonical $\mathrm{Wnt} / \beta$-catenin pathway. The Wnt proteins, and the canonical Wnt/ $\beta$-catenin intracellular signaling pathway, play central roles in development and disease (65), including development of the central nervous system, and are known to promote cell proliferation (66). The Wnt ligands bind to cell surface receptors of the Frizzled $(\mathrm{Fz})$ and low-density lipoprotein-related protein families (67). In canonical Wnt/ $\beta$-catenin signaling, the absence of Wnt ligand causes cytoplasmic signaling components such as glycogen synthase kinase $3 \beta$ (GSK3 $\beta$ ) to phosphorylate $\beta$-catenin, leading to the latter's degradation. Activation of Wnt receptors leads to phosphorylation of GSK3 $\beta$, allowing $\beta$-catenin to accumulate in the cytoplasm. The accumulated $\beta$-catenin translocates to the nucleus, where it interacts with lymphoid enhancer-binding factor 1 with lymphoid enhancer-binding factor 1 (also known as TCF) to activate transcription of Wnt $/ \beta$ catenin target genes $(67,68)$.
In addition to the Wnt receptor Fzd10 and $\beta$-catenin (ctnnb1), one of the TCFs, Tcf711 (also known as TCF-3) was induced by leptin in tadpole brain. This transcription factor is a transcriptional repressor (67) and was recently found to promote growth of colorectal cancers (69). Myc was also identified in our screen and is a Wnt/ $\beta$-catenin target gene that functions in mitosis (70). The cyclin-dependent kinase 10 was induced by leptin and is known to be modulated by Wnt/ $\beta$-catenin signaling $(66,71)$.

There is mounting evidence from different systems and tissues that leptin induction of mitosis and cell survival depends on Wnt $/ \beta$-catenin signaling $(72,73)$. For example, the level of $\beta$-catenin in the cytoplasm is maintained low through continuous proteasome-mediated degradation controlled by a protein complex of GSK3/APC/Axin (65). Phosphorylation of GSK3 on serine 9 by activated $\mathrm{Wnt} / \beta$-catenin signaling leads to destruction of this complex and the accumulation of $\beta$-catenin. $\beta$-Catenin translocates to the nucleus to regulate gene transcription (65). Leptin acts as a growth factor for different kinds of tumor cells 


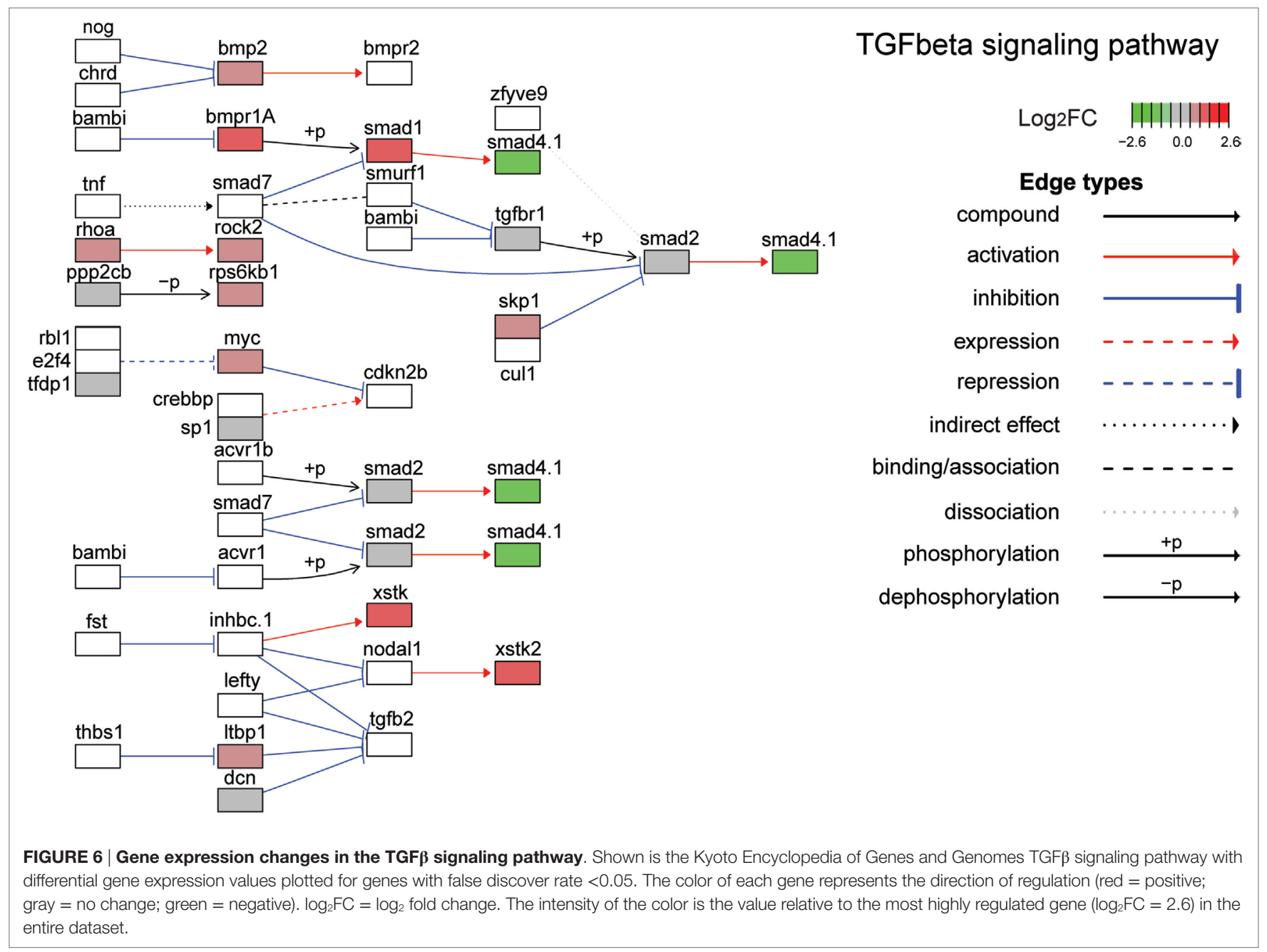

(73, 74), causes rapid nuclear translocation of $\beta$-catenin, and activates other components of the $\mathrm{Wnt} / \beta$-catenin pathway (74-76). Leptin-dependent activation of Wnt/ $\beta$-catenin signaling has also been shown to play a role in leptin action in the adult hypothalamus to modulate glucose homeostasis and energy balance (77-80).

\section{Leptin Modulates TGF $\beta$, Hedgehog, and Insulin Signaling in Xenopus Tadpole Brain}

After the Wnt/ $\beta$-catenin pathway, the next most enriched pathway activated by leptin in tadpole brain was that regulated by the TGF $\beta$ superfamily of ligands, in particular bone BMP and activin. The TGF $\beta$ signaling pathway plays central roles in animal development, including cell proliferation, cell differentiation, and apoptosis $(81,82)$. Several components of this pathway were modulated by leptin in tadpole brain, including ligands, cell surface receptors, and receptor-activated transcription factors of the SMAD family (see Figure 6).

The hedgehog signaling pathway was also found to be activated by leptin (Figure S1 in Supplementary Material). A proposed mechanism of leptin-induced neurogenesis in murine transient amplifying neuroblasts involves hedgehog signaling regulation (83). We also found that leptin modulated components of the insulin signaling pathway (see Figure S2 in Supplementary Material). Interactions between leptin and insulin signaling, and potential therapeutic uses for leptin in normalizing type 2 diabetes have been described recently (84-86). The signal transduction pathways initiated by insulin and leptin are both distinct and overlapping. For example, leptin activates the JAK2-STAT pathway, while insulin activates the mitogen-activated protein kinase pathway. Both insulin and leptin appear to activate the PI3K pathway. Recent findings show that insulin can potentiate leptin signaling (87).

\section{Leptin and Developmental Programming}

Early life nutrition (from maternal source-placenta or yolk, or from feeding-larva) can influence adipocyte production of leptin in the fetus $(88,89)$ or larva (Xenopus, Melissa Cui Bender and Robert J. Denver, unpublished data). Alterations in hormone production, influenced by nutrition during critical periods of development can affect the timing of development, and exert lasting effects on the structure and function of hypothalamic 

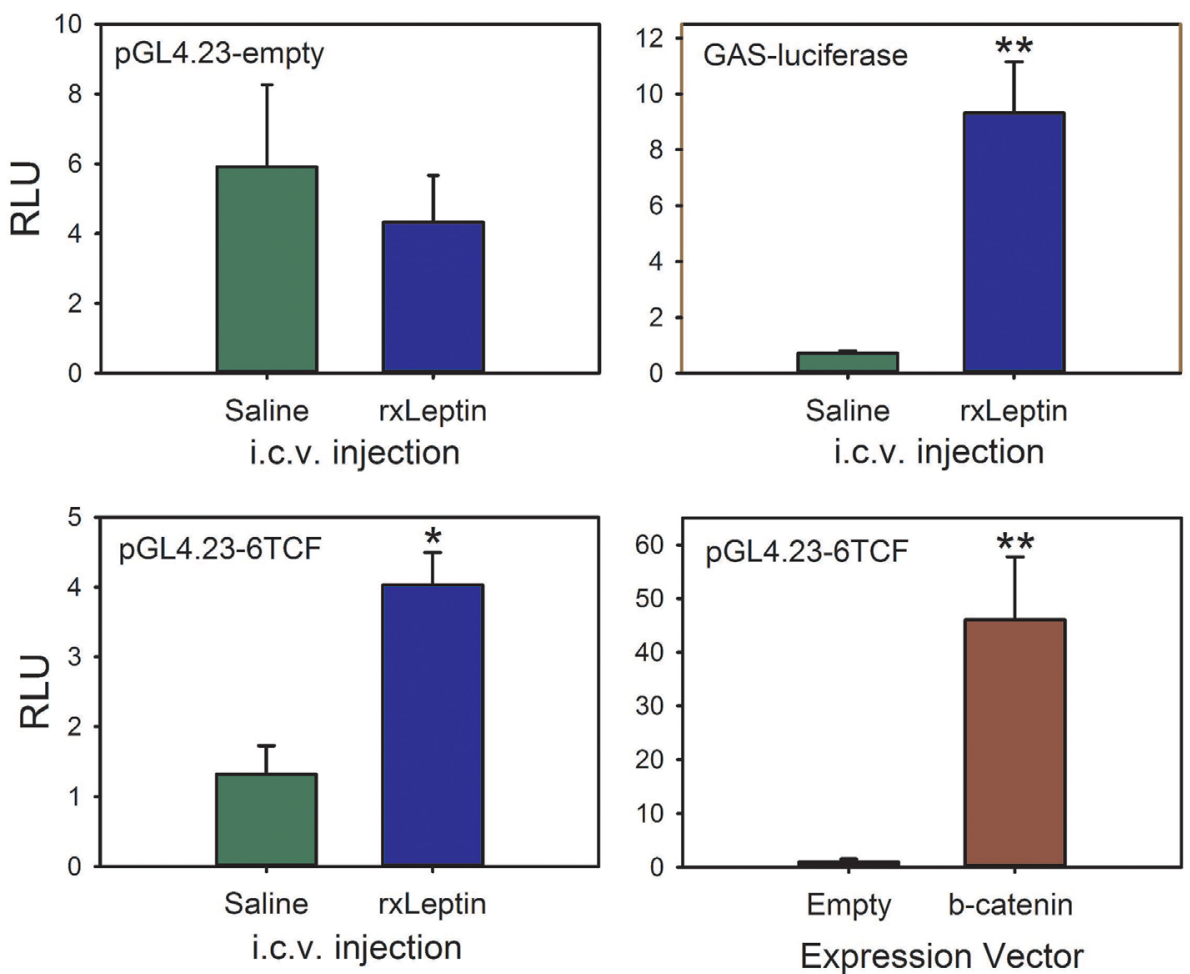

FIGURE 7 | The canonical Wnt/ק-catenin signaling pathway is activated by leptin signaling in Xenopus laevis tadpole brain. We injected plasmids into the region of the third ventricle of premetamorphic (Nieuwkoop-Faber stage 50) tadpoles and transfected them by biopolar electroporation-mediate gene transfer. Twenty-four hours after transfection, we screened tadpoles for EGFP expression, and then separated them into eight groups. The reporter vector is given at the top left of each panel. Tadpoles received intracerebroventricular (i.c.v.) injections of 0.6\% saline or recombinant Xenopus leptin (rxLeptin) (20 ng/g BW); a separate group was cotransfected with the pGL4.23-6TCF reporter vector and either empty expression vector (pCMVneo-empty) or a vector that expresses constitutively active $\beta$-catenin (pcDNA3-S33Y $\beta$-catenin). Two hours after i.c.v. injection, tadpoles were killed and brains harvested for dual-luciferase assay. Asterisks indicate statistically significant differences $\left({ }^{*} p<0.001,{ }^{\star \star} p<0.0001 ; n=8\right.$ tadpoles/treatment).

feeding and neuroendocrine circuits, a phenomenon termed developmental programming (88-93). There is mounting evidence that early life nutrition is an important determinant for risk of obesity (94), and modulation of leptin signaling during critical developmental periods can have long-term consequences for adult physiology (95-99). In animal models, undernutrition during pregnancy leads to a premature leptin surge, and offspring develop leptin resistance as adults, especially following a high-fat diet (100). A decrease or loss of leptin signaling in early postnatal life impairs development of the feeding circuit, and also predisposes individuals to leptin resistance and obesity as adults (95-99, 101-103).

The cellular and molecular mechanisms by which leptin acts on the developing brain to "program" the hypothalamic feeding control circuit are poorly understood (104). One possible mechanism of action is for circulating leptin in the neonate/tadpole to act within neurogenic zones of the developing brain to induce expansion of a LepR expressing cell population, which ultimately establishes the leptin-responsive network in the hypothalamus and other brain regions. Mammals develop competence to respond to leptin signaling during early postnatal development $(15,16,105)$; amphibians develop competence to respond to leptin during early premetamorphosis (Melissa Cui Bender and Robert J. Denver, unpublished data). Functional LepR is detected in the VZ/SVZ during early postnatal development in rodents (18) and premetamorphosis in Xenopus (Figure 2D). Based on our findings and those in the literature, we hypothesize that leptin acts on the neural progenitor population via Wnt/ $\beta$-catenin signaling to induce mitosis and promote cell survival.

Future fate mapping studies can investigate if cells born in the ependymal layer following leptin injection migrate to and populate the preoptic area and ventral hypothalamus. It will also be interesting to investigate the consequences of aberrant leptin signaling during early postembryonic development on later-life physiology and hypothalamic feeding control centers using the Xenopus model system. Leptin signaling in early stage Xenopus tadpole brain can be easily activated by i.c.v. injection of rxLeptin. Furthermore, cells in the tadpole VZ/SVZ can be transfected by EM gene transfer with expression plasmids (e.g., pCS2-xLepR) to force LepR expression in stem/progenitor cells, followed by injection of rxLeptin i.c.v. to activate LepR signaling. We predict that forced expression of LepR in progenitor/stem cells in the developing brain will promote proliferation followed by differentiation of these cells into the LepR expressing lineage. 


\section{ETHICS STATEMENT}

All procedures involving animals were conducted under an approved animal use protocol (PRO00006809) in accordance with the guidelines of the Institutional Animal Care and Use Committee at the University of Michigan.

\section{AUTHOR CONTRIBUTIONS}

$\mathrm{MB}$ participated in the design of experiments, conducted the leptin mRNA analysis, immunohistochemistry for $\mathrm{pH} 3$, DNA microarray analyses and electroporation-mediated gene transfer, and participated in writing the manuscript. CS did the bioinformatics analyses of the DNA microarray data and participated in

\section{REFERENCES}

1. Morton GJ, Cummings DE, Baskin DG, Barsh GS, Schwartz MW. Central nervous system control of food intake and body weight. Nature (2006) 443:289-95. doi:10.1038/nature05026

2. Denver RJ, Bonett RM, Boorse GC. Evolution of leptin structure and function. Neuroendocrinology (2011) 94:21-38. doi:10.1159/000328435

3. Londraville RL, Macotela Y, Duff RJ, Easterling MR, Liu Q, Crespi EJ. Comparative endocrinology of leptin: assessing function in a phylogenetic context. Gen Comp Endocrinol (2014) 203:146-57. doi:10.1016/j.ygcen.2014. 02.002

4. Ahima RS, Osei SY. Leptin signaling. Physiol Behav (2004) 81:223-41. doi:10.1016/j.physbeh.2004.02.014

5. Myers MG, Cowley MA, Munzberg H. Mechanisms of leptin action and leptin resistance. Annu Rev Physiol (2008) 70:537-56. doi:10.1146/annurev. physiol.70.113006.100707

6. Wauman J, Tavernier J. Leptin receptor signaling: pathways to leptin resistance. Front Biosci (Landmark Ed) (2011) 16:2771-93. doi:10.2741/ 3885

7. Xu AW, Kaelin CB, Takeda K, Akira S, Schwartz MW, Barsh GS. PI3K integrates the action of insulin and leptin on hypothalamic neurons. J Clin Invest (2005) 115:951-8. doi:10.1172/JCI200524301

8. Steppan CM, Swick AG. A role for leptin in brain development. Biochem Biophys Res Commun (1999) 256:600-2. doi:10.1006/bbrc.1999.0382

9. Udagawa J, Hashimoto R, Suzuki H, Hatta T, Sotomaru Y, Hioki K, et al. The role of leptin in the development of the cerebral cortex in mouse embryos. Endocrinology (2006) 147:647-58. doi:10.1210/en.2005-0791

10. Udagawa J, Hatta T, Hashimoto R, Otani H. Roles of leptin in prenatal and perinatal brain development. Congenit Anom (2007) 47:77-83. doi:10.1111/ j.1741-4520.2007.00150.x

11. Desai M, Li T, Ross MG. Fetal hypothalamic neuroprogenitor cell culture: preferential differentiation paths induced by leptin and insulin. Endocrinology (2011) 152:3192-201. doi:10.1210/en.2010-1217

12. Desai M, Li T, Ross MG. Hypothalamic neurosphere progenitor cells in low birth-weight rat newborns: neurotrophic effects of leptin and insulin. Brain Res (2011) 1378:29-42. doi:10.1016/j.brainres.2010.12.080

13. Bouret SG, Draper SJ, Simerly RB. Formation of projection pathways from the arcuate nucleus of the hypothalamus to hypothalamic regions implicated in the neural control of feeding behavior in mice. J Neurosci (2004) 24:2797-805. doi:10.1523/JNEUROSCI.5369-03.2004

14. Bouret SG, Draper SJ, Simerly RB. Trophic action of leptin on hypothalamic neurons that regulate feeding. Science (2004) 304:108-10. doi:10.1126/ science. 1095004

15. Bouret SG, Simerly RB. Minireview: leptin and development of hypothalamic feeding circuits. Endocrinology (2004) 145:2621-6. doi:10.1210/en.2004-0231

16. Bouret SG, Simerly RB. Development of leptin-sensitive circuits. J Neuroendocrinol (2007) 19:575-82. doi:10.1111/j.1365-2826.2007.01563.x

17. Ahima RS, Prabakaran D, Flier JS. Postnatal leptin surge and regulation of circadian rhythm of leptin by feeding - implications for energy homeostasis writing the manuscript. RD participated in the design of experiments, analysis of the data, and in writing the manuscript.

\section{ACKNOWLEDGMENTS}

This research was supported by a grant from the National Science Foundation (IOS 0641587) to RD. The authors thank Caroline Hu for technical assistance with pSTAT3 IHC, and Ken Cadigan and Eric Fearon for providing plasmids.

\section{SUPPLEMENTARY MATERIAL}

The Supplementary Material for this article can be found online at http://journal.frontiersin.org/article/10.3389/fendo.2017.00099/ full\#supplementary-material.

and neuroendocrine function. J Clin Invest (1998) 101:1020-7. doi:10.1172/ JCI1176

18. Cottrell EC, Cripps RL, Duncan JS, Barrett P, Mercer JG, Herwig A, et al. Developmental changes in hypothalamic leptin receptor: relationship with the postnatal leptin surge and energy balance neuropeptides in the postnatal rat. Am J Physiol Regul Integr Comp Physiol (2009) 296:R631-9. doi:10.1152/ ajpregu.90690.2008

19. Cottrell EC, Mercer JG, Ozanne SE. Postnatal development of hypothalamic leptin receptors. Vitam Horm (2010) 82:201-17. doi:10.1016/S0083-6729 (10)82011-4

20. Udagawa J, Hatta T, Naora H, Otani H. Expression of the long form of leptin receptor $(\mathrm{Ob}-\mathrm{Rb})$ mRNA in the brain of mouse embryos and newborn mice. Brain Res (2000) 868:251-8. doi:10.1016/S0006-8993(00)02334-9

21. Ishii Y, Bouret SG. Embryonic birthdate of hypothalamic leptin-activated neurons in mice. Endocrinology (2012) 153:3657-67. doi:10.1210/en 2012-1328

22. Prokop JW, Schmidt C, Gasper D, Duff RJ, Milsted A, Ohkubo T, et al. Discovery of the elusive leptin in birds: identification of several 'missing links' in the evolution of leptin and its receptor. PLoS One (2014) 9:e92751. doi:10.1371/journal.pone.0092751

23. Crespi EJ, Denver RJ. Leptin (ob gene) of the South African clawed frog Xenopus laevis. Proc Natl Acad Sci U S A (2006) 103:10092-7. doi:10.1073/ pnas.0507519103

24. Cui MY, Hu CK, Pelletier C, Dziuba A, Slupski RH, Li C, et al. Ancient origins and evolutionary conservation of intracellular and neural signaling pathways engaged by the leptin receptor. Endocrinology (2014) 155:4202-14. doi:10.1210/en.2014-1301

25. Nieuwkoop PD, Faber J. Normal Table of Xenopus laevis (Daudin). New York: Garland Publishing Inc. (1994).

26. Crespi EJ, Denver RJ. Roles of stress hormones in food intake regulation in anuran amphibians throughout the life cycle. Comp Biochem Physiol A Mol Integr Physiol (2005) 141:381-90. doi:10.1016/j.cbpb.2004.12.007

27. Hu F, Knoedler JR, Denver RJ. A mechanism to enhance cellular responsivity to hormone action: Kruppel-like factor 9 promotes thyroid hormone receptor-beta autoinduction during postembryonic brain development. Endocrinology (2016) 157:1683-93. doi:10.1210/en.2015-1980

28. Bagamasbad P, Howdeshell KL, Sachs LM, Demeneix BA, Denver RJ. A role for basic transcription element-binding protein 1 (BTEB1) in the autoinduction of thyroid hormone receptor beta. J Biol Chem (2008) 283:2275-85 doi:10.1074/jbc.M709306200

29. Manzon RG, Denver RJ. Regulation of pituitary thyrotropin gene expression during Xenopus metamorphosis: negative feedback is functional throughout metamorphosis. J Endocrinol (2004) 182:273-85. doi:10.1677/joe.0.1820273

30. Denver RJ, Hu F, Scanlan TS, Furlow JD. Thyroid hormone receptor subtype specificity for hormone-dependent neurogenesis in Xenopus laevis. Dev Biol (2009) 326:155-68. doi:10.1016/j.ydbio.2008.11.005

31. Saka Y, Smith JC. Spatial and temporal patterns of cell division during early Xenopus embryogenesis. Dev Biol (2001) 229:307-18. doi:10.1006/ dbio. 2000.0101 
32. Schreiber AM, Das B, Huang HC, Marsh-Armstrong N, Brown DD. Diverse developmental programs of Xenopus laevis metamorphosis are inhibited by a dominant negative thyroid hormone receptor. Proc Natl Acad Sci U S A (2001) 98:10739-44. doi:10.1073/pnas.191361698

33. Nishinakamura R, Matsumoto Y, Matsuda T, Ariizumi T, Heike T, Asashima M, et al. Activation of Stat3 by cytokine receptor gp130 ventralizes Xenopus embryos independent of BMP-4. Dev Biol (1999) 216:481-90. doi:10.1006/ dbio. 1999.9518

34. Tuinhof R, Gonzalez A, Smeets W, Roubos EW. Neuropeptide Y in the developing and adult brain of the South African clawed toad Xenopus laevis. J Chem Neuroanat (1994) 7:271-83. doi:10.1016/0891-0618(94)90018-3

35. Yao M, Westphal N, Denver R. Distribution and acute stressor-induced activation of corticotrophin-releasing hormone neurones in the central nervous system of Xenopus laevis. J Neuroendocrinol (2004) 16:880-93. doi:10.1111/j.1365-2826.2004.01246.x

36. Irizarry RA, Hobbs B, Collin F, Beazer-Barclay YD, Antonellis KJ, Scherf U, et al. Exploration, normalization, and summaries of high density oligonucleotide array probe level data. Biostatistics (2003) 4:249-64. doi:10.1093/ biostatistics/4.2.249

37. Gautier L, Cope L, Bolstad BM, Irizarry RA. affy - analysis of Affymetrix GeneChip data at the probe level. Bioinformatics (2004) 20:307-15. doi:10.1093/ bioinformatics/btg405

38. Gentleman R, Carey V, Huber W, Hahne F. genefilter: genefilter: methods for filtering genes from high-throughput experiments. R package version 1.50.0.

39. Ritchie ME, Diyagama D, Neilson J, van Laar R, Dobrovic A, Holloway A, et al. Empirical array quality weights in the analysis of microarray data. $B M C$ Bioinformatics (2006) 7:261. doi:10.1186/1471-2105-7-261

40. Smyth GK. Linear models and empirical bayes methods for assessing differential expression in microarray experiments. Stat Appl Genet Mol Biol (2004) 3:Article3. doi:10.2202/1544-6115.1027

41. Yu GC, Wang LG, Han YY, He QY. clusterProfiler: an R package for comparing biological themes among gene clusters. OMICS (2012) 16:284-7. doi:10.1089/omi.2011.0118

42. Supek F, Bosnjak M, Skunca N, Smuc T. REVIGO summarizes and visualizes long lists of gene ontology terms. PLoS One (2011) 6:e21800. doi:10.1371/ journal.pone. 0021800

43. Ogata H, Goto S, Fujibuchi W, Kanehisa M. Computation with the KEGG pathway database. Biosystems (1998) 47:119-28. doi:10.1016/S0303-2647 (98)00017-3

44. Luo WJ, Brouwer C. Pathview: an R/Bioconductor package for pathway-based data integration and visualization. Bioinformatics (2013) 29:1830-1. doi:10.1093/bioinformatics/btt285

45. Merico D, Isserlin R, Stueker O, Emili A, Bader GD. Enrichment map: a network-based method for gene-set enrichment visualization and interpretation. PLoS One (2010) 5:e13984. doi:10.1371/journal.pone.0013984

46. Shannon P, Markiel A, Ozier O, Baliga NS, Wang JT, Ramage D, et al. Cytoscape: a software environment for integrated models of biomolecular interaction networks. Genome Res (2003) 13:2498-504. doi:10.1101/gr.1239303

47. Boorse GC, Kholdani CA, Seasholtz AF, Denver RJ. Corticotropin-releasing factor is cytoprotective in Xenopus tadpole tail: coordination of ligand, receptor, and binding protein in tail muscle cell survival. Endocrinology (2006) 147:1498-507. doi:10.1210/en.2005-1273

48. Haas K, Jensen K, Sin WC, Foa L, Cline HT. Targeted electroporation in Xenopus tadpoles in vivo - from single cells to the entire brain. Differentiation (2002) 70:148-54. doi:10.1046/j.1432-0436.2002.700404.x

49. Yao M, Denver RJ. Regulation of vertebrate corticotropin-releasing factor genes. Gen Comp Endocrinol (2007) 153:200-16. doi:10.1016/j.ygcen. 2007.01.046

50. Yao M, Schulkin J, Denver RJ. Evolutionarily conserved glucocorticoid regulation of corticotropin-releasing factor expression. Endocrinology (2008) 149:2352-60. doi:10.1210/en.2007-1551

51. Kolligs FT, Hu G, Dang CV, Fearon ER. Neoplastic transformation of RK3E by mutant beta-catenin requires deregulation of Tcf/Lef transcription but not activation of c-myc expression. Mol Cell Biol (1999) 19:5696-706. doi:10.1128/MCB.19.8.5696

52. Yao M, Stenzel-Poore M, Denver RJ. Structural and functional conservation of vertebrate corticotropin-releasing factor genes: evidence for a critical role for a conserved cyclic AMP response element. Endocrinology (2007) 148:2518-31. doi:10.1210/en.2006-1413
53. Tonchev AB. Expression of leptin receptor in progenitor cell niches of adult monkey brain. C R Acad Bulg Sci (2008) 61:1219-24.

54. Tata JR. Amphibian metamorphosis as a model for the developmental actions of thyroid hormone. Mol Cell Endocrinol (2006) 246:10-20. doi:10.1016/j. mce.2005.11.024

55. Bouret SG. Development of hypothalamic neural networks controlling appetite. In: Langhans W, Geary N, editors. Frontiers in Eating and Weight Regulation. Basel: S. Karger AG (2010). p. 84-93.

56. Bouret SG. Neurodevelopmental actions of leptin. Brain Res (2010) 1350:2-9. doi:10.1016/j.brainres.2010.04.011

57. Garza JC, Guo M, Zhang W, Lu XY. Leptin increases adult hippocampal neurogenesis in vivo and in vitro. J Biol Chem (2008) 283:18238-47. doi:10.1074/ jbc.M800053200

58. Garza JC, Guo M, Zhang W, Lu XY. Leptin restores adult hippocampal neurogenesis in a chronic unpredictable stress model of depression and reverses glucocorticoid-induced inhibition of GSK-3 beta/beta-catenin signaling. Mol Psychiatry (2012) 17:790-808. doi:10.1038/mp.2011.161

59. Paz G, Wong ML, Licinio J. The procognitive effects of leptin in the brain and their clinical implications. Int J Clin Pract (2010) 64:1808-12. doi:10.1111/j.1742-1241.2010.02536.x

60. Perez-Gonzalez R, Antequera D, Vargas T, Spuch C, Bolos M, Carro E. Leptin induces proliferation of neuronal progenitors and neuroprotection in a mouse model of Alzheimer's disease. J Alzheimers Dis (2011) 24:17-25. doi:10.3233/JAD-2011-102070

61. Avraham Y, Davidi N, Lassri V, Vorobiev L, Kabesa M, Dayan M, et al. Leptin induces neuroprotection neurogenesis and angiogenesis after stroke. Curr Neurovasc Res (2011) 8:313-22. doi:10.2174/156720211798120954

62. Parimisetty A, Dorsemans AC, Awada R, Ravanan P, Diotel N, d'Hellencourt CL. Secret talk between adipose tissue and central nervous system via secreted factors-an emerging frontier in the neurodegenerative research. J Neuroinflammation (2016) 13:67. doi:10.1186/s12974-016-0530-x

63. Tang BL. Leptin as a neuroprotective agent. Biochem Biophys Res Commun (2008) 368:181-5. doi:10.1016/j.bbrc.2008.01.063

64. Wang L, Shao YY, Ballock RT. Leptin synergizes with thyroid hormone signaling in promoting growth plate chondrocyte proliferation and terminal differentiation in vitro. Bone (2011) 48:1022-7. doi:10.1016/j.bone.2011.02.012

65. Logan CY, Nusse R. The Wnt signaling pathway in development and disease. Annu Rev Cell Dev Biol (2004) 20:781-810. doi:10.1146/annurev. cellbio.20.010403.113126

66. Davidson G. The cell cycle and Wnt. Cell Cycle (2010) 9:1667-8. doi:10.4161/ cc.9.9.11595

67. Cadigan KM, Waterman ML. TCF/LEFs and Wnt signaling in the nucleus. Cold Spring Harb Perspect Biol (2012) 4:a007906. doi:10.1101/cshperspect. a007906

68. Clevers $\mathrm{H}$. Wnt/beta-catenin signaling in development and disease. Cell (2006) 127:469-80. doi:10.1016/j.cell.2006.10.018

69. Murphy M, Chatterjee SS, Jain S, Katari M, DasGupta R. TCF7L1 modulates colorectal cancer growth by inhibiting expression of the tumor-suppressor gene EPHB3. Sci Rep (2016) 6:28299. doi:10.1038/srep28299

70. Stephens WZ, Senecal M, Nguyen M, Piotrowski T. Loss of adenomatous polyposis coli (apc) results in an expanded ciliary marginal zone in the zebrafish eye. Dev Dyn (2010) 239:2066-77. doi:10.1002/dvdy.22325

71. Davidson G, Niehrs C. Emerging links between CDK cell cycle regulators and Wnt signaling. Trends Cell Biol (2010) 20:453-60. doi:10.1016/j.tcb. 2010.05.002

72. Doherty GH, Oldreive C, Harvey J. Neuroprotective actions of leptin on central and peripheral neurons in vitro. Neuroscience (2008) 154:1297-307. doi:10.1016/j.neuroscience.2008.04.052

73. Endo H, Hosono K, Uchiyama T, Sakai E, Sugiyama M, Takahashi H, et al. Leptin acts as a growth factor for colorectal tumours at stages subsequent to tumour initiation in murine colon carcinogenesis. Gut (2011) 60:1363-71. doi:10.1136/gut.2010.235754

74. Arita S, Kinoshita Y, Ushida K, Enomoto A, Inagaki-Ohara K. High-fat diet feeding promotes stemness and precancerous changes in murine gastric mucosa mediated by leptin receptor signaling pathway. Arch Biochem Biophys (2016) 610:16-24. doi:10.1016/j.abb.2016.09.015

75. Fenton JI, Lavigne JA, Perkins SN, Liu H, Chandramouli GVR, Shih JH, et al. Microarray analysis reveals that leptin induces autocrine/paracrine cascades to promote survival and proliferation of colon epithelial cells in an 
Apc genotype-dependent fashion. Mol Carcinog (2008) 47:9-21. doi:10.1002/ mc. 20357

76. Yan D, Avtanski D, Saxena NK, Sharma D. Leptin-induced epithelialmesenchymal transition in breast cancer cells requires beta-catenin activation via Akt/GSK3- and MTA1/Wnt1 protein-dependent pathways. J Biol Chem (2012) 287:8598-612. doi:10.1074/jbc.M111.322800

77. Benzler J, Andrews ZB, Pracht C, Stohr S, Shepherd PR, Grattan DR, et al. Hypothalamic Wnt signalling is impaired during obesity and reinstated by leptin treatment in male mice. Endocrinology (2013) 154:4737-45. doi:10.1210/en.2013-1746

78. Benzler J, Ganjam GK, Kruger M, Pinkenburg O, Kutschke M, Stohr S, et al. Hypothalamic glycogen synthase kinase 3 beta has a central role in the regulation of food intake and glucose metabolism. Biochem J (2012) 447:175-84. doi:10.1042/BJ20120834

79. Boucsein A, Benzler J, Hempp C, Stohr S, Helfer G, Tups A. Photoperiodic and diurnal regulation of Wnt signaling in the arcuate nucleus of the female Djungarian hamster, Phodopus sungorus. Endocrinology (2016) 157:799-809. doi:10.1210/en.2015-1708

80. Helfer G, Tups A. Hypothalamic Wnt signalling and its role in energy balance regulation. J Neuroendocrinol (2016) 28:12368. doi:10.1111/jne.12368

81. Moustakas A, Heldin $\mathrm{CH}$. The regulation of TGF beta signal transduction. Development (2009) 136:3699-714. doi:10.1242/dev.030338

82. Ross S, Hill CS. How the Smads regulate transcription. Int J Biochem Cell Biol (2008) 40:383-408. doi:10.1016/j.biocel.2007.09.006

83. Armato U, Chakravarthy B, Chiarini A, Chioffi F, Dal Pra I, Whitfield J. Leptin, sonic hedgehogs, and neurogenesis - a primary cilium's taleon. J Alzheimers Dis (2012) 2:1000e1105. doi:10.4172/2161-0460.1000e105

84. Jackson VM, Breen DM, Fortin JP, Liou A, Kuzmiski JB, Loomis AK, et al. Latest approaches for the treatment of obesity. Expert Opin Drug Discov (2015) 10:825-39. doi:10.1517/17460441.2015.1044966

85. Meek TH, Morton GJ. The role of leptin in diabetes: metabolic effects. Diabetologia (2016) 59:928-32. doi:10.1007/s00125-016-3898-3

86. Stern JH, Rutkowski JM, Scherer PE. Adiponectin, leptin, and fatty acids in the maintenance of metabolic homeostasis through adipose tissue crosstalk. Cell Metab (2016) 23:770-84. doi:10.1016/j.cmet.2016. 04.011

87. Thon M, Hosoi T, Ozawa K. Possible integrative actions of leptin and insulin signaling in the hypothalamus targeting energy homeostasis. Front Endocrinol (2016) 7:138. doi:10.3389/fendo.2016.00138

88. Levin BE. Metabolic imprinting: critical impact of the perinatal environment on the regulation of energy homeostasis. Philos Trans R Soc Lond B Biol Sci (2006) 361:1107-21. doi:10.1098/rstb.2006.1851

89. Plagemann A. Perinatal nutrition and hormone-dependent programming of food intake. Horm Res (2006) 65:83-9. doi:10.1159/000091511

90. Bouret SG. Leptin, nutrition, and the programming of hypothalamic feeding circuits. In: Lucas A, Makrides M, Ziegler EE, editors. Importance of Growth for Health and Development. Basel: S. Karger AG (2010). p. 25-39.

91. Lee DA, Blackshaw S. Feed your head: neurodevelopmental control of feeding and metabolism. Annual Review of Physiology (2014) 76:197-223. doi:10.1146/annurev-physiol-021113-170347

92. Ross MG, Desai M. Developmental programming of appetite/satiety. Ann Nutr Metab (2014) 64 Suppl 1:36-44. doi:10.1159/000360508

93. Sullivan EL, Grove KL. Metabolic imprinting in obesity. In: Langhans W, Geary N, editors. Frontiers in Eating and Weight Regulation. Basel: S. Karger AG (2010). p. 186-94.
94. Lau C, Rogers JM, Desai M, Ross MG. Fetal programming of adult disease implications for prenatal care. Obstet Gynecol (2011) 117:978-85. doi:10.1097/ AOG.0b013e318212140e

95. Bouyer K, Simerly RB. Neonatal leptin exposure specifies innervation of presympathetic hypothalamic neurons and improves the metabolic status of leptin-deficient mice. J Neurosci (2013) 33:840-51. doi:10.1523/ JNEUROSCI.3215-12.2013

96. Djiane J, Attig L. Role of leptin during perinatal metabolic programming and obesity. J Physiol Pharmacol (2008) 59:55-63.

97. Granado M, Garcia-Caceres C, Fuente-Martin E, Diaz F, Mela V, Viveros MP, et al. Effects of acute changes in neonatal leptin levels on food intake and long-term metabolic profiles in rats. Endocrinology (2011) 152:4116-26. doi:10.1210/en.2011-1233

98. Mela V, Diaz F, Lopez-Rodriguez AB, Vazquez MJ, Gertler A, Argente J, et al. Blockage of the neonatal leptin surge affects the gene expression of growth factors, glial proteins, and neuropeptides involved in the control of metabolism and reproduction in peripubertal male and female rats. Endocrinology (2015) 156:2571-81. doi:10.1210/en.2014-1981

99. Walker CD, Long H, Williams S, Richard D. Long-lasting effects of elevated neonatal leptin on rat hippocampal function, synaptic proteins and NMDA receptor subunits. J Neurosci Res (2007) 85:816-28. doi:10.1002/jnr.21173

100. Yura S, Itoh H, Sagawa N, Yamamoto H, Masuzaki H, Nakao K, et al. Role of premature leptin surge in obesity resulting from intrauterine undernutrition. Cell Metab (2005) 1:371-8. doi:10.1016/j.cmet.2005.05.005

101. Attig L, Solomon G, Ferezou J, Abdennebi-Najar L, Taouis M, Gertler A, et al. Early postnatal leptin blockage leads to a long-term leptin resistance and susceptibility to diet-induced obesity in rats. Int J Obes (2008) 32:1153-60. doi:10.1038/ijo.2008.39

102. Bouret SG. Early life origins of obesity: role of hypothalamic programming. J Pediatr Gastroenterol Nutr (2009) 48:S31-8. doi:10.1097/MPG. 0b013e3181977375

103. Vickers MH, Breier BH, Cutfield WS, Hofman PL, Gluckman PD. Fetal origins of hyperphagia, obesity, and hypertension and postnatal amplification by hypercaloric nutrition. Am J Physiol Endocrinol Metab (2000) 279:E83-7.

104. Bouret SG. Organizational actions of metabolic hormones. Front Neuroendocrinol (2013) 34:18-26. doi:10.1016/j.yfrne.2013.01.001

105. Caron E, Sachot C, Prevot V, Bouret SG. Distribution of leptin-sensitive cells in the postnatal and adult mouse brain. J Comp Neurol (2010) 518:459-76. doi:10.1002/cne.22219

Conflict of Interest Statement: The authors declare that the research was conducted in the absence of any commercial or financial relationships that could be construed as a potential conflict of interest.

The handling editor declared a shared affiliation, though no other collaboration, with the authors, and the handling editor states that the process met the standards of a fair and objective review.

Copyright () 2017 Bender, Sifuentes and Denver. This is an open-access article distributed under the terms of the Creative Commons Attribution License (CC BY). The use, distribution or reproduction in other forums is permitted, provided the original author(s) or licensor are credited and that the original publication in this journal is cited, in accordance with accepted academic practice. No use, distribution or reproduction is permitted which does not comply with these terms. 